ББК 65

УДК $336.71 ; 347.734$

\title{
УПРАВЛЕНИЕ ОРГАНИЗАЦИЕЙ В УСЛОВИЯХ ФИНАНСОВОГО КРИЗИСА (НА ПРИМЕРЕ ОАО «СБЕРБАНК РОССИИ»)
}

\author{
А. В. АГЕЕВА \\ Магистрант 2 курса программы «Общий стратегический менеджмент» 080200.68 \\ СПбГЭУ, Санкт-Петербург, Россия
}

\begin{abstract}
Аннотация
В статье автор рассматривает проблему управления организаџией в условиях финансового кризиса, возможность использования руководством антикризисных методов управления, для выхода из сложившейся ситуаџии, на примере ОАО «Сбербанк России».
\end{abstract}

Ключевые слова: бизнес, кризис, организация, управление, экономика.

Abstract

In the article an author examines a management problem organization in the conditions of financial crisis, possibility of the use by guidance of anticrisis methods of management, for an exit from the folded situation, on the example of OAO "Savings Bank of Russia".

Keywords: business, crisis, organization, management, economy

\section{ВВЕДЕНИЕ}

На сегодняшний день, в условиях экономического кризиса данная тема является актуальной, поскольку в ней освещаются проблемы, пути решения, управление в соответствующих условиях.

В настоящее время опубликовано много работ, посвященных вопросам как антикризисного, так и финансового управления предприятиями.

Актуальнейшие проблемы преодоления кризиса на предприятиях получили освещение в трудах таких российских ученых, как: Г. А. Александров, С. Г. Беляев, А. 3. Бобылева, А. П. Богданов, С. В. Валдайцев, М. И. Гончаров, А. Ю. Гончарук, А. П. Градов, А. Г. Грязнова, Н. Д. Гуськова, Н. А. Зайцева, Г. П. Иванов, К. А. Кирсанов, Н. Н. Кожевников, В. И. Кошкин, Э. М. Короткое, Б. И. Кузин, Г. М. Куроше-ва, И. К. Ларионов, Г. А. Лемзяков, Э. С. Минаев, Ю. М. Осипов, В. П. Панагу-шин, Э. А. Уткин и др., а также зарубежных ученых, среди которых, Е. Варга, К. Виксель, Л. Грейнер, У. Джевонс, П. Лагадек, А. Маршалл, К. Маркс, Л. Мендельсон, Дж. Ст. Милль, Дж. Мут, Т. К. Пошан и Э. М. Морэн, К. Ру-Дюфор, Ж.-Б. Сэй, И. Трахтенберг, Ф. Хайек, К. Ф. Херманн, И. Шумпетер и др.

Антикризисное управление стало одним из самых популярных терминов в деловой жизни России. И для этого есть весьма конкретные и очень веские причины. В одних случаях под ним понимают управление фирмой в условиях общего кризиса экономики, в других - управление 
фирмой, в преддверии банкротства, третьи же связывают понятие антикризисное управление с деятельностью антикризисных управляющих в рамках судебных процедур банкротства.

\section{РЕЗУЛЬТАТЫ И ИХ ОБСУЖДЕНИЕ}

Некоторые авторы считают, что антикризисные меры следует принимать, когда финансовое положение функционирующего на рынке предприятия становится уже печальным, а перспектива банкротства - реальной перспективой.

Кризисы неизбежны в деятельности любой организации и получают повсеместное проявление. Более того, финансовый кризис рассматривается не только как неизбежный, но и как необходимый процесс, несущий импульс интенсификации развития организации.

Основной формой проявления финансового кризиса выступает существенное нарушение финансового равновесия организации. Нарушение финансового равновесия организации в период финансового кризиса характеризуется потерей платежеспособности, снижением финансовой устойчивости организации и рядом других параметров, обеспечивающих финансовую безопасность организации в процессе его развития. С учетом этой характеристики финансового кризиса организации, главным объектом усилий антикризисного финансового управления выступает восстановление финансового состояния организации [1].

Особенностью финансового кризиса является его зависимость от внешних условий конъюнктуры финансового рынка, уровня регулирования финансовой деятельности предприятия, степени развития его инфраструктуры, колеблемость которых в динамике носит наиболее интенсивный характер. Вместе с тем, кризис довольно часто возникает и под воздействием негативных внутренних факторов.

Любая форма финансового кризиса приводит к ощутимому потрясению хозяйственной деятельности организации и угрожает ее экономической безопасности. Следует отметить, что финансовый кризис несет не только разрушительную нагрузку, но при эффективном его разрешении имеет прогрессивный характер с позиций обновления отдельных элементов финансовой системы организации и последующей интенсификации его финансовой деятельности.

В настоящее время основным инструментом, характеризующим качество работы кредитной организации, служит анализ ее финансовой деятельности. К огромному сожалению, не всегда данные такого анализа имеют положительные значения [2].

Ухудшение финансового положения значительного числа коммерческих банков является следствием внешних и внутренних причин, обострившихся в банковском секторе.

Внешние причины можно разделить на три вида:

- политические,

- экономические,

- социальные.

К экономическим причинам банковского кризиса можно отнести: 
a) кризисное состояние экономики в целом. Банковская система не может быть сильной в условиях кризисного состояния экономики страны - это часть экономики, которая испытывает на себе весь спектр негативных влияний, включая кризис неплатежей, инфляцию, тяжелое налоговое бремя и т.д.;

б) проведение ЦБ РФ жесткой ограничивающей политики. Поддержание учетной ставки рефинансирования на высоком уровне, повышение норм обязательных отчислений в резервные фонды;

в) введение в ЦБ РФ валютного коридора;

г) немаловажную роль сыграли банковские спекуляции на рынках межбанковских кредитов (депозитов).

К числу важнейших политических факторов можно отнести приближение выборов и принятие связанных с этим популистских решений, в том числе и в денежно-кредитной сфере [3].

К социальным факторам следует отнести падение доверия населения к банкам из-за краха рынка государственных краткосрочных облигаций, валютного рынка.

Внутренние причины - подразделяются на два вида: проблемы управления в коммерческом банке:

а) потери ключевых сотрудников аппарата управления;

б) потеря основных клиентов;

в) участие банка в судебных разбирательствах с непредсказуемым исходом;

е) чрезмерная зависимость банка от какого-либо одного конкретного проекта или вида активов;

ж) излишняя ставка на успешность и прибыльность нового проекта;

3) неэффективные долгосрочные соглашения.

Проблемы, связанные с выбранной политикой работы можно разделить:

а) превышение уровня просроченной кредиторской задолженности;

б) чрезмерное использование дорогих заемных средств в качестве источников финансирования;

в) низкие значения коэффициентов ликвидности;

г) нехватка оборотных средств (функционирующего капитала);

д) увеличивающаяся до опасных пределов доля заемных средств в общей сумме источников средств;

е) превышение размеров заемных средств над установленными лимитами;

ж) наличие просроченной дебиторской задолженности [4].

Воздействовать на внешние причины кризисных явлений одному отдельно взятому банку просто не под силу. Однако, кризис одного банка вполне реально может затронуть всю банковскую систему.

Одной из серьезных причин ухудшения финансового состояния отечественных кредитных организаций являются факты мошенничества и, как результат, преднамеренное или фиктивное 
банкротство. Для преодоления этих причин, кроме усиления контроля над ними и увеличения инспекционных проверок, необходимо совершенствование системы банковской отчетности.

Серьезные проблемы, возникающие у кредитных организаций в настоящее время, могут быть вызваны практикой выдачи льготных кредитов.

В большинстве проблемных кредитных организациях существует практика выдачи льготных или беспроцентных кредитов своим учредителям и работникам, а также некоторым крупным организациям. Большинство проблемных кредитов, выданных как своим учредителям, так и некоторым клиентам, имеют плохое обеспечение. Принятое в залог имущество из-за плохого юридического оформления гарантийных, залоговых и страховых обязательств труднореализуемо. В этой связи необходимо совершенствовать и по возможности законодательно определить перечень ценностей, которые могут быть приняты в качестве обеспечения кредита в современных условиях.

Особая категория клиентов кредитной организации - клиенты, финансирование которых производится из средств местных или федеральных бюджетов [5]. В результате невыполнения бюджетом своих обязательств большинство таких клиентов являются злостными неплательщиками. Надзорным органам в этих условиях необходимо ввести для кредитных организаций, обслуживающих низкорентабельных, но необходимых для экономики клиентов, особый порядок их регулирования по нормативам ликвидности.

Недостаточная величина собственных средств также часто является причиной плохого финансового состояния кредитной организации. Достаточность капитала характеризует степень надежности банка и защищенности средств отдельных категорий депозиторов. При необеспеченности собственными средствами капитальных затрат, распылении фондов и прибыли средства депозиторов в проблемном банке остаются практически ничем не обеспеченными (только невозвратными ссудами и низколиквидными активами). Капитал банка является также показателем допустимого уровня эмитируемых банком векселей и суммы привлеченных вкладов населения.

Существенным фактором сокращения кредитных рисков являются резервы по ссудам. Источником создания резервов в зависимости от категории ссуды являются доходы и чистая прибыль. Однако в настоящее время в банковском законодательстве существуют возможности снизить объемы средств, направляемые в резервы по ссудам, так как банки по своему усмотрению классифицируют ссуды по категориям.

Основные принципы управления и финансового оздоровления кредитных институтов, находящихся в кризисной ситуации, по существу, классифицировал сам Центральный Банк. Определив экспертным путем кризисное состояние кредитной организации, а также принимая во внимание, что банк с подобными показателями и тенденциями в работе может в самом скором будущем доставить серьезнейшие проблемы как региону, в котором он работает, так и свои клиентам, Центральным Банком России (далее ЦБР) или его Региональным подразделением, если они заинтересованы в эффективном функционировании данного кредитного учреждения 
(допустим, оно является одним из составляющих звеньев экономики региона или отрасли, на нем завязаны большинство каких-либо платежей и проч.), может быть принято одно из следующих решений (все нижеуказанные четыре категории мы можем отнести к основным принципам санации (т.е. восстановления финансового состояния) кредитного учреждения):

- ЦБР имеет право направить предписание о замене руководителей и главного бухгалтера банка с целью коренного пересмотра общей политики банка;

- ЦБР может стимулировать мероприятия по реорганизации банка;

- ЦБР вправе ввести в банк временную администрацию с целью проведения политики финансового оздоровления, либо, наоборот, с целью подготовки к реализации программы банкротства;

- ЦБР дает возможность администрации банка разработать и реализовать программу финансового оздоровления кредитного учреждения [3];

Центральный Банк пытается как можно плотнее работать с проблемной кредитной организацией. Ведь к кризисному банку применяется не какой-то конкретный подход (либо замена руководства, либо реорганизация), а весь набор способов и методов, с помощью которых можно выровнять финансовое положение такого банка.

Антикризисные методы воздействия руководства ОАО «Сбербанк России» в условиях кризиса, сводятся к достаточно ограниченному набору методов, таким как сокращение численности персонала, снижение расходов организации, реструктуризации, отказ от большинства проектов, связанных с развитием и расширением бизнеса, временное приостановление выдачи кредитных средств в крупных размерах (предоставление денежных средств на строительство объектов недвижимости).

Метод сокращения численности персонала, в период кризиса не принес ожидаемого результата. Уже к концу 2009 г. банки стали ощущать нехватку кадров, и начался новый набор специалистов. Если подумать, во сколько обошлось обучение сотрудников, создание благоприятной атмосферы в коллективе и недовольство клиентов некачественным обслуживанием, можно прийти к выводу, что сэкономить в данном случае не удалось.

Также, как показывает практика, у сотрудников, постоянно работающих с клиентами в отделениях банка, не хватает времени на дополнительное образование. Чтобы заняться повышением квалификации и дополнительным образованием сотрудников образование должно происходить в рамках кредитной организации - более опытные сотрудники или приглашенные специалисты должны прочитать специальные лекции для сотрудников. В этом случае банк не несет дополнительных расходов на образование или повышение квалификации сотрудников и в то же время повышает их профессиональный уровень, что позволит им улучшить свою эффективность. 


\section{ВЫВОДЫ}

Для усиления ответственности сотрудников и руководства коммерческих банков за результаты своей работы возможно введение дополнительных регулирующих мер. В практике ОАО «Сбербанка России» применяется система депремирования работников, допустивших ошибки в своей профессиональной деятельности. В условиях, когда личная ответственность руководства и сотрудников банков за удачи и неудачи коммерческого банка минимальна, можно было бы законодательно установить определенные ежемесячные отчисления из доходов сотрудников банка в специальный фонд по заработной плате, средства которого депонируются и при обнаружении недостатков в работе персонала банка направляются на погашение убытков.

Необходимо ввести в практику и законодательно закрепить:

- ответственность сотрудников банка при противодействии надзорным органам и внешнему управлению банком вплоть до отстранения от должности, как это практикуется за рубежом;

Необходимо, наряду с уже имеющейся стратегией Сбербанка России, в условиях сложившейся экономической ситуации в стране, разработать антикризисную стратегию.

Антикризисная стратегия должна:

- в первую очередь решать острые проблемы, существующие в коммерческом банке;

- иметь ясно сформулированную цель (например, решение проблемы ликвидности);

- адекватно реагировать на существующие проблемы и идентифицировать причины кризисного состояния.

- быть комплексной, учитывать все сферы деятельности, все внешние и внутренние ресурсы и факторы деятельности;

- включать в себя меры как краткосрочного, так и долгосрочного характера;

- учитывать ограниченность в ресурсах и времени.

\section{ЛИТЕРАТУРА}

1. Стратегия развития банка на период 2014 - 2018 гг. [эл.ресурс] / Режим доступа: www.sberbank.ru. (Дата обращения 01.03.14)

2. Антикризисное управление. 17.09.2012 г. [эл.ресурс] / Режим доступа: www. centeryf.ru (Дата обращения 01.03.14)

3. Кредитование 2013-2014 [эл.ресурс] / Режим доступа: www. credits.ru (Дата обращения 01.03.14)

4. Новости [эл.pecypc] / Режим доступа: www. rbk.ru (Дата обращения 01.03.14)

5. Дроздов, Г.Д. Организационная культура как институциональный фактор развития предприятий сферы услуг / Дроздов Г.Д., Мелехова В.Е. // Теория и практика сервиса: экономика, социальная сфера, технологии № 1 (11), СПб.: изд-во СПбГУСЭ, 2012. С. 123-127 